УАК 338.2(497.115)"1958/1965"(093.2)

37.014.5(497.115)"1958/1965"(093.2)

doi: $10.5937 /$ bastina31-30520

Прегледни раА

Иїор Ђ. ВУКААИНОВИЋ

Балканолошки институт САНУ, БеограА

\title{
ЕКОНОМСКИ И ПРОСВЕТНИ ПРЕОБРАЖАЈ АУТОНОМИЈЕ КОСОВА И МЕТОХИЈЕ (1958-1965)
}

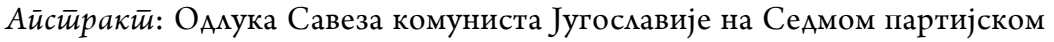
конгресу 1958. године Аа ојача положај националних мањина и посвети посебну пажњу економском развоју Аутономне косовско-метохијске области из корена је променила Аруштвену слику овог простора. ПериоА између 1958. и 1965. гоАине означава епоху најинтензивнијег привредног и просветног развоја аутономије Косова и Метохије. Област је забележила највећу стопу економског раста након Аругог светског рата и отворила нове погоне текстлне, прехрамбене, хемијске и електроиндустрије. Број ученика основних школа је готово уАвостручен, а оснивањем факултета у Приштини и виших школа у Косовској Митровици, Пећи и Призрену, овај простор је премрежен високошколским установама.
\end{abstract}

Кьучне речи: Косово и Метохија, економија, просвета, Савез комуниста Југославије, Приштина, ЕАварА Кардељ, Фадиь Хоџа.

\section{УВОА - УКЬУЧИВАЮЕ ЈУГОС ОВЕНСКОГ ПОАИТИЧКОГ ВРХА У КУАТУРНЕ И ЕКОНОМСКЕ

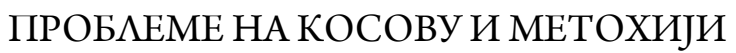

У Аругој половини пеАесетих гоАина југословенски Аржавни и партијски врх почео је Аа показује посебно интересовање за полажај Аутономне косовско-метохијске области у Србији (Гаталовић 2016). Ова промена је објашњавана идеолошким, економским и „реалполитичким“ аргументима. Централни комитет Савеза комуниста Југославије је у децембру 1956. године формирао Комисију за националне мањине, која је почела са радом Ава месеца касније. ЗаАатак Комисије био је Аа се бави проблематиком националних мањина у Југославији, кумтурно-просветног и економског јачања њиховог положаја, али и питањем уАела припаАника мањинских зајеАница

* Истраживач сарадник, vukadinovicigor3@gmail.com 
у Аржавној управи, предузећима, аАминистрацији и у партијским комитетима. ${ }^{1}$ Комисија је на првом заседању 28. фебруара 1957 . године закьучима Аа албанска национална мањина „као најбројнија, има своје властите проблеме“ и Аа је стога неопходно Аа се за њу Аоносе Аиференцијална решења у односу на остале мањинске зајеАнице. ${ }^{2}$ Међутим, комисија је игнорисала чињеницу Аа А^банци чине већину у управљачкој структури Аутономне косовско-метохијске области (Narodni odbor AKMO 1943-1953: 937-953). Националну зајеАницу која је политички Аоминираха у овој аутономној јеАиници, Комисија је третирала као угрожену мањину чији је положај неопходно ојачати. ${ }^{3}$ Комисија за националне мањине је на себе преузела и задатак Аа води бригу о економском и културном положају косовско-метохијске аутономије у Сpбији (Гаталовић 2016: 125-127). ЈеАан оА првих закьучака Комисије био је Аа су Аосадашња умагања у економију Косова и Метохије била „неАовољна“ и Аа економско и културно заостајање Косова и Метохије може Аа има и „негативне политичке послеАице“. ${ }^{4}$ Сличан закьучак донема је и Комисија за националне мањине формирана при Социјалистичком савезу радног народа Југоскавије. ${ }^{5}$

Уплитање савезног нивоа власти у питање положаја аутономне области у Србији интензивирано је у нареАном периоду. Овај приступ додатно је учвршћен у новом партијском програму, који је усвојен на Седмом конгресу СКЈ у Һубьани 1958. године. Осма глава програма односима се на међунационалне односе и у њој је засебна тачка бима посвећена правима националних мањина. СКЈ је као позитивну тенденцију означио повећање удела национамних мањина у „органима Аруштвеног самоуправљања“ и истакао

1 Архив Југославије (АЈ), фонА 507, ЦКСКЈ, XVIII-К.1/1, Стенографске белешке и записник са састанка Комисије за националне мањине, 28. 2. 1957: 4-10.

$2 \mathrm{AJ}, 507$, ЦКСКJ, XVIII-K.1/1, Стенографске бемешке и записник са састанка Комисије за националне мањине, 28. 2. 1957: 1-2.

3 Средином педесетих година, Албанци су чинили преко 60\% посланика у Народном оАбору АКМО. ОА јеАанаест чианова Извршног већа AКМО, шест су били А^банаци, укьучујући и преАсеАника Фадиља Хоџу. Национални састави среских народних оАборауглавном су се поклапали са националним саставом становништва срезова, што је Албанцима омогућило натополовичну већину одборника у свим срезовима, осим Звечанског. Видети: Архив Косова и Метохије (АКМ), Këshili popullor krahinor, 1953, кутија (к.) 8, Витина, ПреглеА ОАржаних сеАница НО општина и НО среза на терену среза Горњоморавског; АК, Këshili popullor krahinor, 1953, к. 9, Срез Источки, ПреглеА одржаних сеАница среског већа, већа произвођача и зајеАничке сеАнице оба већа, 24. Аецембар 1953. ПреглеА оАборника НО општина среза Ситничког за јануар 1953, 12.2. 1953.

4 AJ, 507, ЦК СКJ, XVIII-К.11/2, Подаци о привредној ситуацији националних мањина, стр. 4.

5 AJ, 142, ССРНЈ, фасцикла (ф.) 110, архивска јединица (а.ј.) 782, Извештај Комисије за националне мањине ССРНЈ: Актуемни проблеми националних мањина у Србији, 11. 4. 1959. 
Аа однос Југославије према националним мањинама не зависи оА споьнополитичких односа са сусеАнима земьама (VII kongres Saveza komunista Jugoslavije 1958: 199). У програму је истакнуто Аа је јеАиниство Југославије могуће искьучиво на бази националне равноправности, као и Аа је неопходан услов за то постојање „материјалне основе равноправности“. Ову формукацију албански функционери у партији су искористили Аа покрену кампању за повећање удела Албанаца у структури запослених на Косову и Метохији, која се у пракси спроводима истискивањем Срба и осталих неалбанаца из косовскометохијских предузећа. ${ }^{6}$ Повезивање националног и економског питања Аошло је Ао изражаја у тачки „Стална брига за убрзавање привреАног развитка неразвијених рејона”. Партија се обавезала да ће АоАатно помагати економски развој три најнеразвијеније републике и Аутономне косовско-метохијске области (VII kongres Saveza komunista Jugoslavije 1958: 1055-1056).

Проширени састанак Извршног комитета ЦК СКЈ 2. марта 1959. године у целости је посвећен питању националних мањина у Југославији и економског развоја Аутономне косовско-метохијске области. ЕАварА Кардев је на састанку био најгласнији поборник јачања положаја националнних мањина. Он је предложио Аа се националне мањине у Југославији почну сматрати „пуноправним народима“, а њихови представници пуноправним чиановима југословенског Аруштва (Pelikan 2011: 242). У Закьучцима који су на сеАници усвојени, посебно је изАвојено питање економског развоја заосталих поАручја Југославије. Тада је изричито наведено Аа се СКЈ мора засебно бавити развојем подручја које је настањено „најбројнијом, ацбанском национамном мањином“. На тај начин, ацбанска национамна мањина је бима јеАина национална зајеАница експлицитно споменута у Аокументу. Извршни комитет ЦК CКJ је економски развој подручја настањеног А^банцима означио као кьуч за решавање осталих питања у вези са овом националном мањином (Rajović 1985: 468-470).

Вемика промена у односу СКЈ према аутономији Косова и Метохије и албанској националној мањини у Србији објашњавала се тиме Аа се југословенски врх водио „практичним интересима“, те је проценио Аа економска и културна заосталост Косова и Метохије преАставьају „кочницу“ за развој Југославије и потенцијални извор помитичке нестабимности. Међутим, Савез комуниста Југославије овакав приступ није применио у случају

6 ИАеју отпуштања Срба са посла и запошьавања Албанаца како би се „поправика национална структура запослених“, албански функционери ФаАиь Хоџа и ЏавиА Нимани су први пут споменули на седници Извршног комитета ЦК Србије 27. јануара 1959. године. Видети: АС, Ђ-2, Извршни комитет ЦК СКС, к. 2, Стенографске бемешке са проширене сеАнице Извршног комитета ЦК СК Србије одржане 27. 1. 1959. године, стр. 42,98 . 
српских крајева у Хрватској, који су били готово у потпуности заобиђени индустријализацијом у овим републикама, а покретање овог питања било је строго забрањено у југословенском јавном Аискурсу педесетих и шездесетих година (Bjelajac 2010: 130-131). Инцијатор укьучивања савезног нивоа власти у питање економског положаја Косова и Метохије и отварања питања националних мањина био је ЕАварА КарАењ, заступник курса слабњења Југославије и јачања Аржавности република (Ћосић 2009: 196-197).Због залагања за постепену разградњу југословенске Аржаве, Кардев и словеначко руководство су крајем пеАесетих година дошли у прикривени сукоб са српским руководиоцима, предвођеним Александром Ранковићем. Пошто је у руковоАству Србије препознао препреку за реализацију својих планова, КарАењ је одлучио Аа отварањем мањинског питања и јачањем аутономије Косова и Метохије постави темеље за дестабилизацију Србије и слабњење њеног положаја у Југославији. У нареАном периоду, утицај Србије на Косову и Метохији постајао је све више ограничен савезним наАглеАањем економског развоја АКМО и савезном политиком према националним мањинама.

\section{ЕКОНОМСКИ РАЗВОЈ}

Средином педесетих година у Аутономној косовско-метохијској области је живело око 950.000 ьуди, оА чега је свега 268.000 становника било економски активно, претежно у пољопривреАи. У инАустријској производњи бимо је запослено 31.000 радника. ${ }^{7}$ Перспективни пман Југоскавије оА 1957. Ао 1961. године је као јеАан оА најважнијих цињева истакао развој неразвијених подручја у Аржави. У пракси су „подруча“ поистовећивана са републикама и Аве аутономне јединице у Србији, тако Аа је брига за неразвијене крајеве у Југославији сведена на финансирање развоја Македоније, Црне Горе, Босне и Херцеговине и Аутономне косовско-метохијске области. Прва конкретна мера била је одмука Аа се из савезног буџета изАвоји 80 милијарди динара за Македонију и 50 милијарди Аинара за инвестиције у Аутономној косовско-метохијској области. Највећи Аео Аонације, 22,7 мимијарАи Аинара, изАвојено је за развој индустрије и рударства у обкасти, 16,85 милијарди уложено је у пољопривреду, а остатак је намењен за саобраћај и финансирање Обласног инвестиционог фонда Косова и Метохије (Društveni plan privrednog razvoja Autonomne kosovsko-metohijske oblasti 1958: 19; ur. Ocić, Babić i dr. 1991: 44).

Народни оАбор Аутономне косовско-метохијске области је 28. Аецембра 1957. гоАине усвојио Аруштвени план привреАног развоја АКМО

7 AJ, 142, ССРНJ, ф. 110, а.j. 782, Извештај Комисије за националне мањине ССРНЈ: Актуелни проблеми националних мањина у Србији, 11. 4. 1959. 
оА 1957. Ао 1961. године, који је означио преокрет у економском развоју области. Промена се огледала у векиким инвестицијама, које су се заснивале на финансијској подршци из савезног буџета (Društveni plan privrednog razvoja Autonomne kosovsko-metohijske oblasti 1958: 15-21; Гаталовић 2016: 273-275). ${ }^{8}$ Пианирано је запошьавање 29.000 радника, чиме би укупан број радника на Косову и Метохији био готово удвостручен и износио би 60.000. Циь плана био је раст индустријске производње оА $97 \%$ у односу на 1956. годину и укупан раст БАП-а оА 84,3\% (Društveni plan privrednog razvoja Autonomne kosovsko-metohijske oblasti 1958: 19-21). Аонација југословенског нивоа власти у износу оА педесет милијарди Аинара представљала је окосницу петогодишњег плана 1957-1961. и привреАног процвата области у нареАном периоду (VІ обласна конференција Социјалисиичикоі савеза раgної нароgа Србије за Косово и Метиохију 1961: 21). ЈеАан оА циьева инвестиција било је и повећање националног дохотка по глави становника, који је у Аутономној косовско-метохијској области 1957. године износио 41,6\% оА националног Аохотка по глави становника у Југославији. ${ }^{9}$

ОА 1956. Ао 1960. године укупан национални доходак на Косову и Метохији је порастао за 35,8\%, а у истом периоду бројност радничке класе је повећана за 39\%, пошто је запослено 14.000 нових радника. Већ 1959. године Комисија за националне мањине СКЈ је закьучияа Аа је се „може говорити о економском препороду Косова и Метохије “. ${ }^{10}$ Инвестиције Југославије у привреАу АКМО постале су виАьиве на терену 1961. године, пуштањем у производњу површинског копа Аигнита „Косово“ коА Приштине, руАника олова и цинка „Кишница“, ткачнице памука у Ђаковици, ткачнице свиле у Призрену, фабрике тила у Гњилану и фабрике мепенки у Аипьану (VI обласна конференција 1961: 274; Вукадиновић 2019: 240; Гаталовић 2016: 274). ${ }^{11}$

Највећи пројекат који је завршен 1962. године била је термоемектрана „Косово I“ у Обилићу, а исте године отворене су фабрика шећера у Пећи и фабрика суперфосфата у Косовској Митровици (Николић 1963: 24-25; Гаталовић 2016: 282). Извршене су реконструкције и проширивање капацитета фабрике ува у Урошевцу, предузећа „Мермер“ у Пећи и фабрике за производњу дувана у Гњилану. Укупне инвестције у АКМО оА 1956.

8 AKM, Lidhja e Komunistëve të Kosovës, к. 568, Аевета покрајинска конференција Косова и Метохије 1965, Развој привреде Косова и Метохије у периоду оА 1947. Ао 1963. године са освртом на проблеме развоја оА Осме обласне конференције СКС АО Аанас, стр. 4-5.

9 AJ, 507, ЦК СКЈ, XVIII-К.11/8, Реферат о економском стању у АКМО, 9. 6. 1959.

10 АJ, 507, ЦКСКJ, XVIII-К.11/8, АосаАашњи и будући развој АКМО, 18. 7. 1959: 6.

11 AKM, Lidhja e Komunistëve të Kosovës, к. 568, Аевета покрајинска конференција Косова и Метохије 1965, Развој привреАе Косова и Метохије у периоду оА 1947. Ао 1963. године са освртом на проблеме развоја оА Осме обласне конференције СКС Ао Аанас, стр. 4-7. 
Ао 1960. године износиме су 65 милијарди динара, од чега је 77\% преАстављало неповратну помоћ из федерације. Шездесетих година извршена је реконструкција саобраћајних путева и железничких пруга на Косову и Метохији, и дошио је Ао експанзије саобраћаја. Аок је 1961. године у општини Урошевац шеснаест особа поседовало аутомобиле, девет година касније број власника аутомобима у општини износио је 560 (ур. Маметић, Стојић 1975: 236).

Инвестиције у привредне и непривредне Аелатности АКМО оА 1956. Ао 1960. године биле су три пута веће него инвестиције у периоду 1952-1956. године. БАП на Косову и Метохији је оА 1960. до 1964. године порастао за $58,6 \%$. Отварање великих привреАних објеката омогућимо је Аа се у периоду 1960-1964. године запосли 23.933 нових радника. Савезна помоћ косовскометохијској привреди инстиутционализована је 1961. године, кроз формирање „Фонда за развој недовољно развијених подручја“. Након доношења Устава 1963. године фонд је постао уставна категорија, а 1965. године установьен је „ФонА Федерације за кредитирање бржег развоја привредно неАовољно развијених република и аутономних покрајина“, који је преАставњао јеАан оА кьучних елемената југословенске и косовскометохијске привреде у наредне Аве Аеценије (ur. Ocić, Babić i dr. 1991: 45; Prifti, Verli 1993: 253).

Инвестиције у АКМО 1960-1964. године биле су Ава пут веће у оАносу на инвестиције у претходних пет година. Просечна годишња стопа економског раста на Косову и Метохији од 1957. до 1963. године износила је 7,9\%, што није забележено ни у јеАном другом сеАмогодишњем периоду за време социјализма (Popović 2009: 30 - 32; ur. Hadžibuli, Bašota i dr. 1972). БАП по глави становника је оА 1957. Ао 1964. године порастао за 41,7\% (Gusja 1982: 15; Вукадиновић 2019: 240; Gatalović 2016а: 123) Куьчни фактор поменутих екомонских показатења била су финансијска среАства југословенске федерације, која су у инвестицијама на Косову и Метохији у периоду 1957-1964. године учествовала са преко $70 \%{ }^{12}$

Изузетно амбициозни привредни планови у периоду оА 1957. Ао 1964. године нису остварени у потпуности. Ипак, Покрајински комитет је у извештају који је поднет Аеветој покрајинској конференцији СКС за Косово и Метохију 1965. године констатовао Аа је у протеклом периоду извршен „Аруштвено-економски преображај Косова и Метохије“ (Izveštaj Pokrajinskog komiteta o radu SKS na Kosovu i Metohiji od VIII oblasne do IX pokrajinske konferencije 1965: 8-10).

Корените промене у привреАној структури Косова и Метохије у периоду 1957-1965. године потврђују и статистички подаци. Примарни сектор,

12 АJ, 837, КПР, II-1/130, Титова посета Косову и Метохији, 21. 3. 1967, Проблеми привреАног развоја Косова и Метохије у протеклом периоду, стр. 6. 
који обухвата поьопривреду и шумарство, је 1957. године чинио око 55\% БАП-а на Косову и Метохије, а секундарни сектор, оАносно индустрија и занатство, 34,2\%. Након осам година, 33,1\% БАП-а на Косову и Метохији је Аолазило из примарног сектора, а удео секундарног сектора је порастао на 47,1\%. У истом периоду је забележен раст терцијалног сектора (саобраћај, туризам, банкарство и остале непроизводне делатности) са 10,9\% на 19,8\% (Limani 1980: 57).

Табела 1. Промене у структури привреде Косова и Метохије у периоду између 1957. и 1965. године.

\begin{tabular}{|l|c|c|c|}
\hline & Примарни сектор & Секундарни сектор & Терцијални сектор \\
\hline 1957. година & $54,9 \%$ & $34,2 \%$ & $10,9 \%$ \\
\hline 1965. година & $33,1 \%$ & $47,1 \%$ & $19,8 \%$ \\
\hline
\end{tabular}

Ао крупних промена је дошло и унутар секундарног сектора привреде. Индустрија Косова и Метохије је постала мање зависна оА експлоатације руАних богатстава обојене металургије. Отварање фабрика текстилне индустрије, хемијске инАустрије, електроиндустрије, инАустрије коже и обуће и индустрије Аувана Аовело је Ао смањивања удека тешке индустрије у укупној производњи (Mađaraj 1989: 45). Ипак, рудна богатства Покрајине имала су велики значај и на југословенском нивоу, о чему сведоче подаци о учешћу Косова и Метохије у укупној југословенској производњи одређених производа 1965. године.

Табела 2. Учешће Аутономне покрајине Косова и Метохије у укупној југословенској производњи одређених производа 1965 . године. ${ }^{13}$

\begin{tabular}{|l|c|c|c|}
\hline & Југославија & $\begin{array}{c}\text { Косово } \\
\text { и Метохија }\end{array}$ & $\begin{array}{c}\text { учешће АП КиМ } \\
\text { упроизводњи СФРЈ }\end{array}$ \\
\hline електрична енергија & $15.523 \mathrm{kWh}$ & $963 \mathrm{kWh}$ & $6,2 \%$ \\
\hline угаљ & $29.957 .000 \mathrm{t}$ & $2.438 .000 \mathrm{t}$ & $8,1 \%$ \\
\hline олово-цинкане руде & $2.358 .000 \mathrm{t}$ & $1.987 .000 \mathrm{t}$ & $84,2 \%$ \\
\hline рафинисано олово & $101.504 \mathrm{t}$ & $81.638 \mathrm{t}$ & $80,4 \%$ \\
\hline каустично печени магнезит & $28.163 \mathrm{t}$ & $21.529 \mathrm{t}$ & $76,4 \%$ \\
\hline сребро & $129 \mathrm{t}$ & $116 \mathrm{t}$ & $89,9 \%$ \\
\hline
\end{tabular}

РуАнички комплекс Трепча преАстављао је јеАан оА највећих руАничких постројења у Југославији, захваљујући чему је граА Косовска Митровица остварио брз економски и демографски успон (Симијановић 2018: 244245). У привреди Косова и Метохије шездесетих година постојао је проблем

13 АJ, 837, КПР, II-1/130, Посета преАседника Тита Косову и Метохији 25-28. марта 1967, Бемешка у вези пута Тита на Косово и Метохију, Проблеми привредног развоја Косова и Метохије у протеклом периоду, стр. 10. 
неуједначене развијености општина. Косовска Митровица је 1960. године остварила национални доходак по глави становника који је износио $136 \%$ оА југословенског просека. С Аруге стране, општина Арагаш, као најсиромашнија у АКМО, остварила је Аоходак по глави становника у износу оА свега $10 \%$ оА југословенског просека. ${ }^{14}$

Заостајање Косова и Метохије у Аруштвеном развоју бимо је нарочито изражено у сфери зАравства. Болести дигестивног тракта и инфективне бомести су, усмеА ниског нивоа хигијене, на овом простору биме присутније него у остатку Југославије (Рopović 2009: 35 - 36). Био је присутан и проблем недостатка квалификованог медицинског каАра (Трајковић 2009: 332333). На целој територији АКМО је 1958. године радимо укупно 68 мекара опште праксе и 7 стоматолога, што је бимо недовољно за расуће зАравствене потребе становништва (Narodni odbor Autonomne kosovsko-metohijske oblasti 1958 - 1959 1962: 762). И на овом подручју остварен је напреАак током шездесетих година, иако је и на крају те деценије број мекара у покрајини био недовољан (Живковић 2011: 141).

Подаци о економском процвату Косова и Метохије у периоду 1957-1964. године Аемантују распрострањену тезу о „угњетавању А^банаца“ у времену док је Александар Ранковић заузимао високе државне функције у Југославији. Велике југословенске инвестиције у област спречиле су масовне економске миграције становника Косова и Метохије у остале крајеве Југославији. Повећање животног стандарда у овом периоду утицамо је и на повећање наталитета, а Косово и Метохија је шездесетих година преАставьало јеАино подручје Југославије на којем се број живорођене Аеце повећавао. Економски процват АКМО крајем педесетих година поклопио се са првим извештајима о безбедносном притиску на неалбанско становништвом и појави политички мотивисаног исељавања Срба са Косова и Метохије (Јевтић 1990: 38) Процеси угрожавања Срба и њиховог исељавања Аодатно су интензивирани након Брионског пленума 1966. године (Ристановић 2018: 255-256).

\section{РАЗВОЈ ОБРАЗОВАҢА}

Подручје Косова и Метохије је након Аругог светског рата имамо око $70 \%$ неписменог становништва, због чега је питање школства на овом простору заузимало посебно место у политици Савеза комуниста Југославије (Islami 1982: 220). ПореА организовања течајева за описмењавање, партијски функционери су предузимали мере развоја школске мреже,

14 АJ, 507, ЦКСКЈ, XVIII-К.11/14, Неки основни подаци о Аосадашњем развоју АКМО, стр. 15-16. 
а главни циљ био је повећање броја ученика и наставника у области. Војници и официри НОВJ, који су поседовали учитеьско образовање повучени су са фронта и укьучени у наставу. Учитељи и наставници који су бики ангажовани у просветном систему фашистичке Вемике Албаније оА 1941. Ао 1944. године, заАржани су на послу. (Narodni odbor Autonomne kosovsko-metohijske oblasti 1943-1953 1953: 28). ${ }^{15}$

Највећи изазов основног и среАњег образовања у области био је неАостатак квалификованих просветних раАника. УслеА политике брзог ширења школске мреже овај проблем није могао бити решен у кратком року. Школске 1958/1959. године око 70\% албанских учитеља и наставника у АКМО је бимо неквалификовано. На Косову и Метохији 1959. године није постојала нијеАна шкома у којој су сви просветни раАници имали неопходне стручне квамификације. ${ }^{16}$ Власти су овај проблем најпре решавале кроз стручне педагошке курсеве у Приштини и Призрену, а током педесетих година у учитеьским школама отворена су Аодатна одеьења за запослене неквалификоване учитеье и наставнике. Школске 1962/1963. гоАине 493 учитеља на Косову и Метохији, оА којих су 373 били Албанци, похађами су ова одеьења у учитеьским шкомама у Приштини, Призрену, Ђаковици, Урошевцу, Гњиману, Косовској Митровици и Вучитрну. ${ }^{17}$ Неквалификовани учитеьи запослени у настави су учитељске школе уместо за четири завршаваки за Аве године. ПореА тога, многи оА њих су похађахи и метње семинаре на којима су припремани за помагање преАмета учитеьске шкоме. ${ }^{18}$

Власти АКМО су 1957. године оАлучиме Аа већу пажњу посвете и материјалном аспекту школства. Многе шкоме су биле смештене у неодговарајућим објектима и зградама које нису испуњавале педагошке и хигијенске услове. Аешавало се и аа се школска настава принудно обавьа у приватним кућама, џамијама и кафанама (Narodni odbor Autonomne kosovsko-metohijske oblasti 1953: 747; Славковић 2018: 467). Народни оАбор Аутономне косовско-метохијске области је 1957. године Аонео ОАлуку о условима за изграАњу школских зграда и опреме, према којој је прописано Аа све школске граде убудуће морају испуњавати неопходне урбанистичко-педагошке критеријуме. ОАлуком је преАвиђено Аа сваки пројекат школске зграде претхоАно мора Аобити сагласност оА комисије Савета за школство (Narodni odbor Autonomne kosovsko-metohijske oblasti 1956-1957 1961: 705-707).

15 АЈ, 315, Комитет за школе и науку при Влади ФНРЈ, ф. 3, а.ј. 883.

16 АJ, 507, ЦКСКЈ, XVIII-К.9/22, Аматерске и професионалне културно-просветне установе; Куктурно-просветни проблеми национални мањина, стр. 5.

17 АЈ, 318, ф. 94, а.j. 127, Проблем неписмености (1962-1967), Ваншколски облици образовања одраслих у АКМО, стр. 6-7.

18 АJ, 507, ЦКСКЈ, XVIII-К.9/22, Аматерске и професионалне културно-просветне установе; Културно-просветни проблеми национални мањина, стр. 6 
У скиаду са смерницама Министарства просвете из 1945. године, припаАници националних мањина похађали су наставу на матерњем језику, а језик републике у којој су се налазиле похађали су у фонду оА три часа неАељно. ${ }^{19}$ Албански ученици слушали су наставу на албанском језику, а 1951. године уведена је и настава на турском језику за припаднике турске националне мањине. ${ }^{20}$ Број ученика на Косову и Метохији перманентно је растао педесетих и шездесетих година (Privredni i društveni razvoj SAP Kosova 1947-1972 1974: 125). ${ }^{21}$

Табела 3. Промене броја ученика основних школа на Косову и Метохији оА 1956. Ао 1965. године, према наставном језику.

\begin{tabular}{|l|c|c|c|c|}
\hline & укупно & српски & албански & турски \\
\hline $1956 / 1957$. & 122.091 & 40.224 & 78.395 & 2.472 \\
\hline $1965 / 1966$. & 202.514 & 67.719 & 131.607 & 3.188 \\
\hline
\end{tabular}

У Аругој половини пеАесетих година предузете су мере са циьем зближавања српских и албанских ученика. У првој послератној Аеценији школе за српске, албанске и турске ђаке биле су физички одвојене по националној припадности ученика, а оА 1956/1957. године уведене су „мешовите шкоме“, у којима се настава похађама на различитим језицима. ${ }^{22}$

Школске 1957 / 1958. године српски ђаци на Косову и Метохији добили су прилику Аа уче албански језик и књижевност као изборни школски преАмет у фонду од три часа недељно. Практични разлози утицали су на то Аа се велики проценат српских ученика определио за учење албанског језика. Успех који је остварен на овом плану истакнут је и у извештају Покрајинског комитета СКС за Косово и Метохију на Аеветој покрајинској партијској конференцији 1965. године (Бонџић 2008: 88/97; Izveštaj Pokrajinskog komiteta o radu SKS na Kosovu i Metohiji od Osme oblasne do Devete pokrajinske konferencije 1965: 51). ${ }^{23}$ Аруги потез који је имао за циь смањивање националне нетрпељивости у школству бимо је увођење јеАинственог програма историје за српске, албанске и турске ђаке. ОА школске 1957/1958. године

19 АJ, 507, ЦКСКЈ, XVIII-К.9/12, Основне карактеристике оствареног културно-просветног живота и рада националних мањина у НРС, 1958; Мањинско школство.

20 АJ, 130, СИВ, ф. 993, Записник са сеАнице ОАбора за унутрашњу политику Савезног извршног већа, одржане 19. Аецембра 1957. године, Проблем исељења Турака из Југославије.

21 АЈ, 319, ф. 31, Анализа Аруштвеног плана САП Косова 1965-1970. Аруги део: Остварени развој образовања и културе у САП Косову и основне пројекције развоја до 1975. године, стр. 7.

22 АJ, 507, ЦКСКJ, XVIII-К.9/16, Записник са састанка Савета за просвету о питању националних мањина, 1958.

23 AJ, 507, ЦКСКJ, XVIII-К.9/22, Аматерске и професионалне културно-просветне установе; Културно-просветни пробкеми национални мањина, стр. 7. 
Аеца на Косову и Метохији похађала су историју по истом програму, који је претежно био сачињен оА српске и југословенске историје, али и мекција посвећених албанској и турској историји. ${ }^{24}$ ПоА притиском албанских функционера у Покрајинском комитету, 1963. године извршена је промена програма историје у виду повећања броја кекција посвећених историји Албаније (Imami 2015: 212).

Аеца и родитељи су се педесетих година ретко опредељивали за наставак образовања након завршетка осмогодишње основне школе, на шта указују и статистички подаци. Основне школе на Косову и Метохији је 1961. године похађамо 167.301 ђака, док је у среАње шкоме и гимназије ишло око Аванаест пута мање Аеце, свега 13.332 ученика. ${ }^{25}$ Успорени развој образовања Аругог ступња на Косову и Метохији био је повезан са недовољним присуством наставе на албанском језику. Аок је у основним школама настава за националне мањине извођена на матерњем језику, у школама Аругог ступња, нарочито стручним школама, настава се углавном одвијала на српском језику, због чега су албанска деце ретко наставьала школовање. Школске 1961/1962. године, број албанских ученика у косовскометохијским основним школама је био за 70\% већи оА броја деце која су наставу похађала на српском језику, Аок су у средњим школама српски ученици још увек чинили натполовичну већину. ${ }^{26}$

Савет за просвету Аутономне косовско-метохијске области и ОАбор за просвету Народног собрања МакеАоније су 1959. године преАложили Савезном секретаријату за образовање Аа се настава на матерњем језику за националне мањине у већој мери уведе у средње школе. ПреАлог је образможен потребом да се повећа број стручних каАрова у Области. Комисија ССРНЈ за националне мањине такође је подржаяа преАлог за среАњошколску наставу на језицима националних мањина. ${ }^{27}$ Кампања за уписивање Аеце у среАње школе и гимназије започета је 1959. године и резултирала је тиме Аа се број ђака у Аругом степену образовања оА 1959. Ао 1964. године повећао Ава и по пута. У истом периоду, УАвостручен је број просветних радника у школама Аругог ступња (Izveštaj Pokrajinskog komiteta o radu SKS na Kosovu i Metohiji od Osme oblasne do Devete pokrajinske konferencije 1965: 24).

$24 \mathrm{AJ}, 318, \phi .24$, a.j. 32, Програм наставе историје у основним шкомама са шиптарским и турским наставним језиком, стр. 1-6.

25 АЈ, 318, ф. 24, Извештај о раду Савета за просвету АКМО за 1961. годину, стр. 6-7.

26 АJ, 318, ф. 43, а.ј. 58, Писмо преАсеАника ОАбора за просвету Народног собрања НР Македоније Аимче Миреа Савезном секретаријату за образовање и културу, 8. 1. 1959.

$27 \mathrm{AJ}, 318$, ф. 43, а.ј. 58, Мишьење и примедбе Савета за просвету АКМО на материјал Савезног секретаријата за образовање о школама националних мањина, 31. јануар 1959, стр. 4. 
Језик је преАставьао баријеру и за развој високог школства коА албанске националне мањине. А^банску интемигенцију у Југославији су пеАесетих година углавном чинима мица која су образовање стекла у међуратној Албанији и фашистичкој Италији. Зекерија Реџа (1910-1972), који је 1942. године оА стране владе Мустафе Крује поставьен за директора гимназије у окупираној Ђаковици, током педесетих година је био Аиректор албанског књижевног часописа у Приштини „Нови живот“. Пошто је А^банолошки институт у Приштини, у чијем раду је учествовао, затворен 1955. године због ширења национализма, Реџа је затражио Аа му се Аозволи пресељење у А^банију, тако да се 1958. године настанио у Тирани (ur. Elsie 2004: 147; ур. Павловић, Гаталовић и Ар. 2012: 97, 100). ${ }^{28} \mathrm{Ha}$ катедри за албанологију Филозофског факултета у Београду раАили су Антон Чета (1920-1995) и ИАриз Ајети (1917-2019). Чета, који је међуратни период провео у А^банији, за време Аругог светског рата вратио се на Косово и Метохију, радећи као професор у гимназији у Призрену. Ајети је након окупације Југославије 1941. године постао италијански стипендиста у Падови (Milanović 1990: 71-77) Марк Краснићи (1920-2015), који је током пеАесетих година радио на Ентографском институту САНУ, такође је за време рата студирао у Итакији. Чета, Краснићи и Ајети су у извештајима Управе Аржавне безбеАности означени као носиоци ацбанског национализма. ${ }^{29}$

Извршни комитет ЦК СКС је 27. јануара 1959. године расправьао о питањима у вези са положајем националних мањина у Србији, а јеАна оА тема била је и албанска интемигенција у Југославији. ПреАсеАник Извршног већа АКМО ФаАиь Хоџа таАа је стао у оАбрану ацбанске интемигенције оА оптужби за национамизам, поручивши Аа је свака интекигенција склона национализму. Он је истакао значај који албанска интелигенција треба Аа има за развој Косова и Метохије и потребу обласних институција за образованим кадровима који су завршими факултете. Хоџа је закьучио Аа је непријатеьски став који су југословенске вмасти заузимале према ацбанској интелигенцији у претходном периоду само погоршао стање и продубио неразумевање. ${ }^{30}$

Косовскометохијски Албанци ретко су се опредељивали за студирање на југословенским факумтетима педесетих година, што је бимо условьено културним, економским и политичким размозима. Високообразовне

28 Архив Србије (АС), фонА Безбденосно-информативне агенције (БИА), III-121, Реферати о шиптарској националној мањини.

29 АС, БИА, III-136, Извештај о непријатељској дематности и антисоцијалистичким појавама у срединама просветних радника, средњошколске и студентске омладине на Космету, а.j. 15-18.

30 АС, Ђ-2, Извршни комитет, к. 2, Стенографске белешке са проширене седнице Извршног комитета ЦК СК Србије оАржане 27. јануара 1959. године, стр. 98. 
институције које у похађали у највећем броју биле су Виша пеАагошка школа у Скопьу и Фимозофски факултет у БеограАу..${ }^{31}$ Албански студенти у БеограАу и осталим универзитетским центрима у Југославији углавном су се међусобно повезивали, избегавајући Аруштвену асимикацију у југословенској средини. 3бог таквог Аржања и неАовољне комуникације са осталим студентима, критиковани су оА стране студентских удружења. ${ }^{32} \mathrm{C}$ Аруге стране, албански студенти су износили жалбе Аа имају неравноправан третман на југословенским факулетима и да у студентским организацијама наилазе на негативну Аискриминацију. ${ }^{33}$

Оснивањем Више педагошке школе у Приштини 1958. године постављен је темељ за развој високог школства у Области (VI обласна конференција 1961: 38). Савезни секретаријат за образовање и културу је 1955. године утврдио Аа је у Аутономној косовско-метохијској обцасти свега $2,8 \%$ наставника у основним школама имало завршену Вишу пеАагошку школу, Аок је на ниову Србије тај проценат износио 63\%. То је утицало на оАлуку Аа Приштина постане пети граА у Србији са вишом пеАагошком школом. Развоју високошколске мреже на Косову и Метохији Аопринео је став СКЈ Аа треба повећати број високообразованих А^банаца у Аржави. $^{34}$

Након отварања Више пеАагошке школе, мрежа виших и високих шкома на Косову и Метохији почела је брзо Аа се шири. Наредне, 1959. године основана је Виша управна школа у Приштини и Виша економско-комерцијална школа у Пећи. Виша пољопривредна школа у Приштини основана је 1960. године. Филозофски факултет, основан 1960. године био је први факултет у Области и у почетку је саАржао оАсеке за језике и природно-математичке науке (VI обласна конференција 1961: 38; Вукадиновић 2008: 52). Следеће, 1961. године основан је Правно-економски факултет у Приштини, у чији састав је укьучена и дотадашња Виша управна школа. У Приштини и Косовској Митровици су 1961. године основане Аве више техничке шкоме, а 1962. године Фимозофски факултет је отворио одељења за историју, географију и пеАагогију. СлеАећи факултет у Приштини био је Технички факултет, формиран 1965. године. У Призрену је 1961. године основано

31 AJ, 507, ЦКСКJ, XVIII-K.11/18, Студенти Аржављани ФНРЈ по народности 1955/1956.

32 АС, Ђ-2, Извршни комитет, к. 2, Стенографске белешке са проширене седнице Извршног комитета ЦК СК Србије одржане 27. јануара 1959. године, стр. 93.

33 АС, БИА, III-136, Извештај о непријатеьској декатности и антисоцијалистичким појавама у среАинама просветних раАника, среАњошколске и студентске омладине на Космету, а.j. 16.

34 Више педагошке шкоме у Србији су до тада постојале у Београду, Нишу, Зрењанину и Крагујевцу. Опширније виАети: АJ, 318, ф. 51, а.j. 66, Школе за образовање настаника за обавезно школовање (Стање, проблеми, предлози), стр. 5-6. 
одељење Више пеАагошке шкоме у Приштини, које је 1962. године постало одвојена високошколска институција.

Косово и Метохија је почетком шезАесетих година имаха четири граАа у којима су биле смештене високошколске институције. НијеАан регион у Србији јужно оА БеограАа није имао толико граАова са високошколским установама. За размику оА Пећи, Косовске Митровице и Призрена, градови сличне величине у Центрахној Србији Крушевац, Аесковац, Краљево и Врање почетком шезАесетих година нису имали више школе. На вишим шкомама и факултетима у Аутономној косовско-метохијској области школске 1960/1961. године студирамо је 1.707 студената. Наредне године број стуАената је већ износио 3.516. (Вукадиновић 2008: 52). ${ }^{35}$ Настава на овим високошколским установама одвијала се на српском и албанском језику, а У Аругој помовини 1963. године број студената албанске националности са Косова и Метохије први пут је престигао број студената српске национа ности из Покрајине. Ао 1965. гоАине број студената на Косову и Метохији Аостигао је $6.000 .^{36}$ Високошколске установе на Косову и Метохији су Ао 1969. голине формално биле Аео Универзитета у Београду, али су, у складу са југословенском праксом, имаме изузетно широку аутономију и самостално су уређивале своју Аелатност (ВукаАиновић 2008: 52).

Оснивање факултета и виших школа учврстило је положај Приштине као културног и економског регионалног центра, у који су почели Аа се Аосељавају становници из осталих крајева Југославије. Могућност стицања високог образовања на албанском језику довела је до тога Аа су у Приштину почели Аа домазе Албанци из МакеАоније, Црне Горе и општина у Централној Србији (Никомић 1963: 47). Преказак албанских научника, професора и студената из Београда у Приштину Аовео је Ао тога да је албанолошки смер на Филозофском факултету у Београду школске 1961/1962. године уписао само јелан студент. У формирање косовскометохијских факултета ушио се са неАовољним бројем квалификованих предавача, а нису бима регулисана ни бројна организациона питања. Током шездесетих година биме су присутне и међунационамне нетрпемивости међу наставницима, које су посебно Аомазиме Ао изражаја примиком избора нових предавача. ${ }^{37}$

35 АЈ, 318, ф. 24, Извештај о раду Савета за просвету АКМО за 1961. годину, стр. 8.

36 Према подацима Секретаријата Покрајинског комитета СКС за Косово и Метохију, у покрајини је 1965/1966. године студирало 4.000 редовних и 6.000 ванреАних студената. Видети: АС, Савез комуниста Косова, к. 3, Седница Секретаријата Покрајинског комитета Савеза комуниста Србије за Косово и Метохију одржане 10. 1.1966. године. Информација о неким актуелним питањима на вишим школама и факултетима.

37 АС, БИА, III-136, Извештај о непријатељској дематности и антисоцијалистичким појавама у срединама просветних радника, среАњошколске и студентске омладине на Космету, а.j. 17-18. 


\section{ЗАКЬУЧАК}

Током 1957. и 1958. године Савез комуниста Југославије предузео је мере са циьем економског и просветног јачања косовскометохијске аутономије. Савезна комисија за националне мањине налглеАала је материјални и културни положај Албанаца у Србији, а Савезно извршно веће дотирало је економски развој Косова и Метохије. ПривреАни план 1957-1961. је из корена променио економску структуру Аутономне косовско-метохијске области, што се огмеАало у отварању нових погона електропривреде, хемијске, текстилне и прехрамбене индустрије. Економски развој Косова и Метохије оА 1961. Ао 1965. гоАине обележен је изузетно високим стопама привреАног раста. Индустрија Косова и Метохије је у поменутом периоду отворила нове перспективе и постала мање зависна оА експлоатације рудних богатстава, а покрајински руководиоци су 1965. године говорили о „Аруштвено-економском преображају Косова и Метохије“. Поменуте промене омогућене су инвестицијама са савезног и републичког нивоа, које су у укупним инвестицијама на Косову и Метохији учествовале са преко 70\%. Ипак, упркос великом расту бруто-Аруштвеног производа по глави становника, он је, услеА високог природног прираштаја и брзог раста попукације, остао на ниском нивоу у поређењу са остатком Југославије.

Повећање стручног ангажмана и материјалних укагања крајем педесетих година омогућили су Аа школске зграде у Аутономнохј косовско-метохијској области почну Аа испунњавају модерне урбанистичке, хигијенске и пеАагошке стандарде. У циьу побољшања међунационалних односа српски, албански и турски ученици из истих места почели су Аа похађују школе у истим објектима, а за српске ђаке је увеАен албански језик као изборни предмет. Кампања за развој средњег образовања на Косову и Метохији покренута крајем педесетих година резултирала је увећавањем броја ученика средњих школа за Ава и по пута у периоду оА 1959. Ао 1964. године. Формирање мреже факултета у Приштини и високошколских установа у Митровици, Пећи и Призрену, омогућимо је Аа се, упркос почетном заостатку, Косово и Метохија шездесетих година нађе у привилегованом економском и просветном положају у односу на Централну Србију.

\section{ИЗВОРИ}

Архив Југославије

- фондови: Социјалистички савез радног народа Југославије (142); Савезни секретаријат за образовање и културу (318); Савезни савет за образовање и културу (319); Централни комитет Савез комуниста Југославије (507); Кабинет преАсеАника Републике (837). 
Архив Србије

- фондови: Безбедносно-информативна агенција; Централни комитет Савеза комуниста Србије (Ђ-2); Савез комуниста Косова.

Архив Косова и Метохије, Приштина

- фондови: Савез комуниста Косова (Lidhja e Komunistëve të Kosovës); Обласни народни oАбop (Këshili popullor krahinor).

\section{АИТЕРАТУРА}

Ћосић 2009: Аобрица Ћосић. Аична истиорија јеgної gоба. Време искушења 1951-1968. БеограА: Службени гласник.

Hadžibulić, Bašota 1972: Muris Hadžibulić, Nuri Bašota i dr. ur. Privredni sistem SFRJ. Prvi deo. Osnove privrednog sistema Jugoslavije, Beograd: Institut za ekonomiku investicija.

VІ обласна конференција Социјалисииччкоі савеза раgної нароgа Србије за Косово и Метиохију. Приштина. Обласни оАбор ССРНС за Косово и Метохију: 1961.

VII kongres Saveza komunista Jugoslavije. Ljubljana 22-26. aprila 1958. Stenografske beleške. Beograd. Kultura: 1958.

Bjelajac 2010: Mile Bjelajac. „Proizvođenje novih nacija, novih manjina i teritorijalna pitanja (Koncept konkurentske države na tlu Srbije)". The shared history. Nations, states and diasporas of the former Yugoslavia. Zbornik radova. Ur. Darko Gavrilović. Sremska Kamenica: Fakultet za evropske pravno-političke studije, 121-142.

Бонџић 2008: Арагомир Бонџић. „ЈеАан документ о Авојезичном школству на Косову и Метохији 1961. године“. Архив, год. IX, бр. 1-2, 88-97.

Вукадиновић 2008: Зоран Вукадиновић. „Приштински универзитет и његове библиотеке, Савремена библиотека, год. ХХ, бр. 25, 52-55.

Вукадиновић 2019: Игор Вукадиновић. „Југословенска социјална политика на Косову и Метохији (1945-1974)“. Социјална ӣолитичка у Србији на раскрићу векова. 3борник радова. Ур. Владимир Илић. Београд: Висока школа социјалног рада, 235-245.

Гаталовић 2016: Миомир Гаталовић. Косово и Метиохија у gржавној йолийищи Јуіославије 1958-1965. БеограА: Институт за савремену историју.

Gatalović 2016 b. Miomir Gatalović. „Uticaj otvaranja nacionalnog pitanja u Jugoslaviji na kreiranje državne politike prema Kosovu i Metohiji 1964-1965”. Istorija 20. veka, god. XXXVI, br. 2, 117-136.

Gusja 1982: Ismet Gusja. Prirodni izvori i privredni razvoj SAP Kosova. Priština: Jedinstvo.

Društveni plan privrednog razvoja Autonomne kosovsko-metohijske oblasti 1957-1961. Priština. Zavod za privredno planiranje Autonomne Kosovsko-metohiske oblasti: 1958.

Elsie 2004: Robert Elsie, ur. Historical dictionary of Kosova. Lanham: Scarecrow Press.

Живковић 2011: Микутин Живковић. „Посета Јосипа Броза Тита Косову и Метохији (25 - 28.

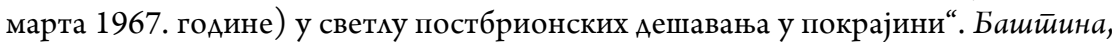
св. 30, 135-151.

Imami 2015: Nailje Malja-Imami. „Školstvo na albanskom jeziku na Kosovu i jugu Srbije (1945-2015)“. Figura neprijatelja. Preosmišljavanje srpsko-albanskih odnosa, Zbornik radova. Ur. Aleksandar Pavlović. Beograd: Institut za filozofiju i društvenu teoriju, 211-227.

Islami 1982: Hivzi Islami. „Nepismenost u današnjem kosovskom selu“. Sociologija sela, br. 20 (77/78), 219-232. 
Izveštaj Pokrajinskog komiteta o radu SKS na Kosovu i Metohiji od Osme oblasne do Devete pokrajinske konferencije. Priština. Pokrajinski komitet Saveza komunista Srbije za Kosovo i Metohiju: 1965.

Јевтић 1990: Атанасије Јевтић. Сӣраgање Срба на Косову и Мейохији оg 1941. gо 1990. Приштина: ЈеАинство.

Limani 1980: Musa Limani. Investicije i privredni razvoj Socijalističke autonomne pokrajine Kosovo, Priština: Zavod za udžbenike i nastavna sredstva SAP Kosova.

Mađaraj 1989: Binak Mađaraj. Ekonomska aktivnost stanovništva SAP Kosova (Ekonomsko - demografska studija). Priština: Zavod za udžbenike i nastavna sredstva Socijalističke autonomne pokrajine Kosovo, 1989.

Малетић, Стојић 1975: Михајмо Малетић, Иван Стојнић. Урошевац и околина. БеограА: Борба.

Narodni odbor Autonomne kosovsko-metohijske oblasti 1956-1957. Priština. Naordni odbor Autonomne kosovsko-metohijske oblasti: 1961.

Narodni odbor Autonomne kosovsko-metohijske oblasti 1958-1959. Priština. Narodni odbor Autonomne kosovsko-metohijske oblasti: 1962.

Николић 1963: Миодраг Николић. Косово и Мейохија. Преі̄леg gрушиивено-економскої развитика. Београд: Седма сила.

Nuši 1977: Pajazit Nuši. Saradnja Univerziteta u Prištini i Univerziteta u Tirani. Priština: Pokrajinski centar za marksističko obrazovanje "Ideje i akcije".

Ocić, Babić 1991: Časlav Ocić, Stojan Babić i dr., ur. Privredni razvoj Kosova i Metohije. Beograd: Naučna knjiga.

Павловић, Гаталовић и Ар. 2012: Момчимо Павловић, Миомир Гаталовић и Ар. ур. Косово и Метиохија: Век важних gоїађаја 1912-2012. БеограА: Институт за савремену историју.

Pelikan 2011: Jan Pelikan. „Pristup Titovog režima Kosovu krajem pedesetih godina“. Tito - Viđenja i tumačenja. Zbornik radova. Ur. Olga Manojlović Pintar. Beograd: Institut za noviju istoriju, 235-246.

Popović 2009: Nenad Popović. Economic history and perspectives of Kosovo and Metohija. Belgrade: Fond „Srpski ekonomski centar“.

Prifti, Verli 1993: Kristaq Prifti, Maranglen Verli, „Ascpetcs of the economic situation of Kosova (1980-1989)“. The truth on Kosova. Zbornik radova. Ur. Kristaq Prifti. Tirana: Encyclopaedia Publishing House, 242-260.

Privredni i društveni razvoj SAP Kosova 1947-1972. Priština. Pokrajinski zavod za statistiku SAP Kosova: 1974.

Rajović 1985: Radošin Rajović. Autonomija Kosova. Istorijsko-pravna studija. Beograd: Ekonomika.

Ристановић 2018: Петар Ристановић. „Југословенски програм мера и активности за заус-

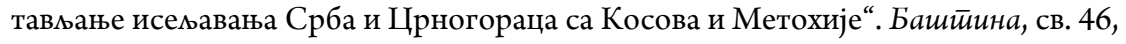
255-272.

Симијановић 2016: Јован Симијановић. „Примог историји пословања „Трепче“ (19441956) “, Башиичина, св. 46, 241-254.

Славковић 2018: Божица Славковић: Политичке, економске и кулйурне йрилике на Косову и Метиохији 1919-1941. БеограА: Просвета-Принцип, 2018.

Трајковић 2009: Радомир Трајковић. Каменица са околином (хроника). 


\title{
Igor Đ. VUKADINOVIĆ
}

\author{
THE ECONOMIC AND EDUCATIONAL TRANSFORMATION \\ OF THE AUTONOMY OF KOSOVO AND METOHIJA (1958-1965)
}

\section{SUMMARY}

Decision of the League of Communists of Yugoslavia to pay special attention to the development of the Autonomous Region of Kosovo and Metohija has radically changed the economic structure of the region. This was reflected in the opening of new plants in the electrical, chemical, textile and food industries, which was followed by the high rates of economic growth. These changes were made possible by investments from the federal and republican levels, which accounted for over $70 \%$ of total investments in Kosovo and Metohija. Data on the economic boom of Kosovo and Metohija in the period 1957-1964. years deny the myth of the "oppression of Albanians" while Aleksandar Rankovic was in positions of power.

The increase in professional engagement and material investments at the end of the fifties enabled school buildings in Kosovo and Metohija to meet modern urban, hygienic and pedagogical standards. In order to improve interethnic relations, Serbian, Albanian and Turkish students from the same places started attending schools in the same facilities, and the Albanian language was introduced as an elective subject for Serbian students. During the 1950s, Kosovo Albanians rarely chose to study at Yugoslav universities, driven by cultural, economic and political considerations. The situation changed after 1958, with the establishment of the Higher Education School in Pristina. The faculty network expanded in the following years, so that in the early 1960s, Kosovo and Metohija had four towns that housed higher education institutions. Pristina has become the cultural, economic and educational center of this part of Yugoslavia.

Key words: Kosovo and Metohija, economy, culture, education, Fadil Hoxha, Edvard Kardelj, Socialist Yugoslavia

РаА је преАат 14. Аецембра 2020. године, а након мишьења рецензената, оАлуком оАговорног

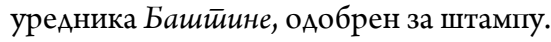

